\title{
LEPROSY IN NORTHERN RHODESIA
}

Northern Rhodesia is a large country $(290,320$ sq. miles) with a scattered population of about 1,376,000, of which some ten thousand are Europeans. It is some six times the size of Nyasaland, yet it has a smaller population than that country. Communications are difficult, and important centres are far apart. It was accordingly not possible to reach all the places I should have liked to visit in the fourteen days at my disposal, though with the use of air transport I was able to include such far apart places as Fort Jameson and Balovale (. es $^{\prime} \epsilon^{\prime}$ map).

\section{NuMBl:R OF L.HPliRs}

No census of leprosy has yet been attempted; the most reliable figures are those based chiefly upon tax-exemption statistics; but, as the practice with regard to exemption of lepers from taxes varies in different districts, the figures even as a gauge of comparative frequency are only approximate, and they only represent a fraction of the whole number of lepers.

The official figures for 1934 in the five provinces are shown in Table I.

\section{TABLE I}

\begin{tabular}{|c|c|c|c|c|c|c|}
\hline \multicolumn{2}{|l|}{ Province } & \multirow{2}{*}{$\begin{array}{c}\text { Area } \\
60,890\end{array}$} & \multirow{2}{*}{$\begin{array}{r}\text { Population } \\
232003\end{array}$} & \multirow{2}{*}{ Lepers } & $\begin{array}{l}\text { Lepers per } \\
\text { sq. mile }\end{array}$ & $\begin{array}{l}\text { Lepers per } \\
\text { mille }\end{array}$ \\
\hline Barotse & $\ldots$ & & & & 0.07 & I3.I4 \\
\hline Eastern & $\ldots$ & 22,350 & 242,662 & I7 8 & 0.008 & 0.73 \\
\hline Northern & $\ldots$ & 80,385 & 399,277 & 918 & 0.01 & 2.30 \\
\hline Central & $\ldots$ & 68,7 IO & I63,676 & 485 & 0.007 & 2.96 \\
\hline Southern & $\ldots$ & 48,335 & I96,757 & 802 & 0.016 & 4.07 \\
\hline & & 280,670 & $\mathrm{I}, 334,465$ & 6,748 & & \\
\hline
\end{tabular}

It is apparent from these figures that Barotseland is the most affected province, and this seems to be the general consensus of opinion of administrative and medical officers.

\section{Types of Cases}

I had an opportunity of visiting three leper settlements conducted by missions receiving Government grants, viz. Mwami (Seventh Day Adventists), Nsadzu (Dutch Reformed), Fiwila (U.M.C.A.), also two leper camps attached to Government hospitals at Mongu and Balovale. I examined the patients at these institutions and classified them according to the type of disease, dividing them into five groups : (I) Severe open cases 
$\left(L_{2}\right.$ and $\left.L_{3}\right)$; (2) Slight open cases $\left(L_{1}\right)$; (3) Patients with definite tuberculoid lesions; (4) Those with flat macules, including residual; (5) Those with no active signs. Each group is again subdivided into those with and those without definite deformity and disablement. Males and females are given separately. This classification is an approximate one, as bacteriological examination results were in many cases not available. The results are as follows :-

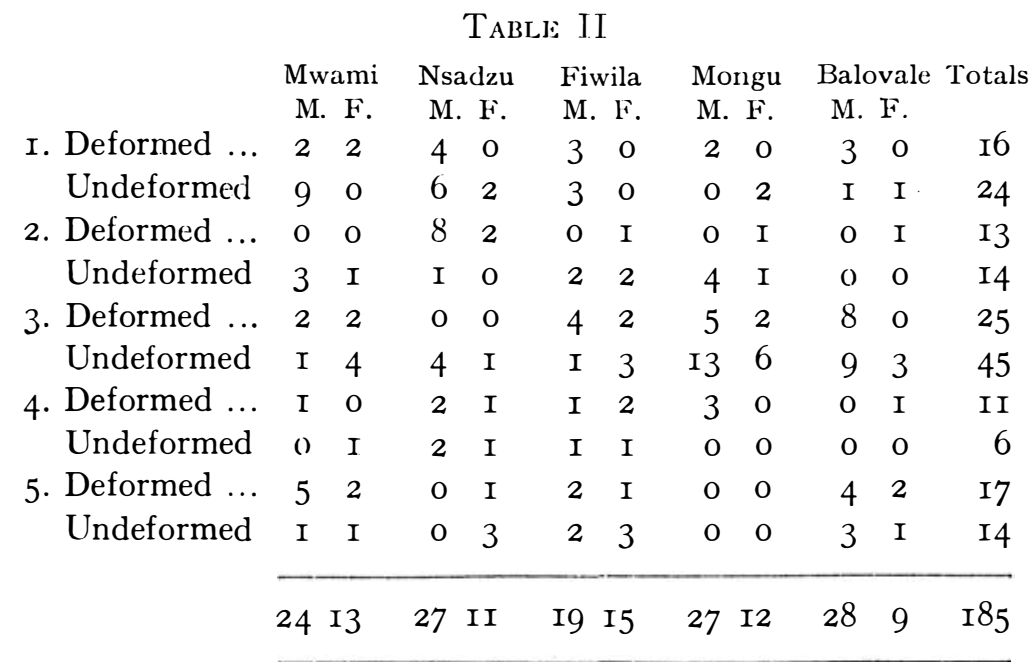

There are also some two or three other leper settlements which lack of time prevented me from visiting; but the whole number of lepers provided for by institutions is not more than two hundred and fifty.

We can, to a limited extent, take the above figures as an index of the proportions of the different types of leprosy present in the regions served by the various institutions. It may be noticed that patients with definite tuberculoid lesions form 37.8 per cent of the whole, and severe open cases 2I per cent. But if the figures of the first three institutions are taken separately those with tuberculoid lesions form only 22 per cent, and severe lepromatous cases 28 per cent; while those from Mongu and Balovale have over 60 per cent of tuberculoids and only II per cent of severe open cases. The proportion of tuberculoid cases is thus nearly three times as great in the Barotseland (Mongu and Balovale) figures as in those of the other institutions, while the latter show $2 \frac{1}{2}$ times as many severe open cases.

In the institutions visited in Nyasaland the percentages of tuberculoid and severe open cases were respectively I2 and 35; and in that seen in the Belgian Congo they were 35 and 24. The significance of these figures is better seen as arranged in Table III. 
TABLE III

Barotseland Congo East N.Rhod. Nyasaland

Percentage of cases with

Tuberculoid Lesions ... 60

Severe Open Cases ... II

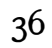

22
22

28
I2

35

It is seen that the proportion of cases with tuberculoid lesions diminishes, and that of severe open cases increases, as one passes from Barotseland to Nyasaland. As severe open cases indicate susceptibility, and tuberculoid indicate resistance to the disease, it might at first sight be supposed from the above figures that leprosy is of a milder type in Barotseland than in the Central and Eastern Provinces of Northern Rhodesia and in Nyasaland.

However, it has already been shown in the official figures, which correspond with the consensus of opinion, that leprosy is much more common in Barotseland than elsewhere. We have thus the curious phenomenon of a preponderance of the milder type of leprosy in the region where there is the highest number of cases.

I suggest the following explanation of this phenomenon.

The majority of any population is naturally resistant to leprosy, and a small minority are highly susceptible. When the latter are infected they are liable to develop a severe open type, especially if the general health is depressed by malnutrition or complicating cliseases. Comparatively short and slight contact with an open leper may be sufficient to produce leprosy in such a case. A much more prolonged and close contact, however, is necessary to produce the disease in the resistant case, and only the milder type with tuberculoid lesions is likely to occur.

It has already been argued in the report on Nyasaland (p.I4) that the type of leprosy there is on the whole mild, as compared with that in India, Burma and the far east. Lepra reaction, a sign of great susceptibility, seldom occurs, trophic ulcers are slight and comparatively uncommon, there are very few child lepers; all these indicate racial resistance. The same indications of a mild type are present also in Barotseland.

The difference between these two regions is, to use a metaphor, not in the bacillary seed, nor yet in the basic nature of the body soil, but in the intensity with which it is cultured. The people in Barotseland are, I understand, dirty and promiscuous in their habits; the population is condensed along the Zambesi River; the climate is warm and moist and biting insects form a plague, create irritation of the skin and favour the scratching in of lepra bacilli; precautions are not as a rule taken to isolate infectious cases and prevent the spread of infection. Whereas the people of Nyasaland are better educated, cleaner, and less promiscuous in their habits, and are accustomed to take more precautions to prevent themselves being infected. Presupposing equal racial resistance and the same proportion of susceptibles in each of the two regions, we should expect slightly fewer severe cases in Nyasaland, as susceptible 
individuals are liable to acquire the disease whether their contact is major or minor; but we should expect a much smaller number of cases of the resistant type in Nyasaland where the chances of intensive infection are so much less. Thus the conditions expected would appear to correspond with the limited facts known.

Nutrition. There is reason to believe that malnutrition has an important bearing on leprosy. This country would form a suitable place for the study of this factor. Dr. Board has suggested to me that casava as a basic diet has something to do with the high incidence of leprosy in Barotseland, and Dr. Meiklejohn mentioned the same in connection with the highly leprous area bordering on Lake Bangweulu. This is a matter that needs careful consideration.

Tax Remission. In Table I the number of lepers given is based chiefly upon those that apply for and obtain tax remission. The custom varies in different districts, but in Balovale it is usual to remit the tax of six shillings to all who are considered to be suffering from leprosy, however slight their lesions. The reason for this is that it is the custom to earn money with which to pay taxes by working at the mines; those with leprosy are refused at the mines, and it is therefore difficult for them to earn money to pay the tax. In consequence a slight patch which is definite leprosy, but which remains the same for years, is highly prized, as it remits the tax and yet gives no inconvenience to the " sufferer." This tax remission, as at present practised, seems to hinder rather than help the control of leprosy. I had an opportunity of examining some 50 labourers at the Roan Antelope Copper Mine. I was struck with their fine physique and with the fact that though a large proportion come from highly leprous Balovale, none of them showed even the slightest signs of leprosy. This, however, is easly explained by the custom regarding taxexemption.

\section{LEPROSY INSTITUTIONS}

The following are short notes on the leper settlements and camps visited, or with which I was able to establish contact.

Mwami. A report on this settlement appears in the Nyasaland Report, as it is situated near the border about 12 miles from Fort Jameson, and receives grants and patients from both countries. It is under Miss Ingle, a Nursing Sister of the Seventh Day Adventist Mission. I saw 37 patients, though others were absent in the fields. There is no medical supervision. The housing is good. The patients are somewhat lazy, but the Sister is doing all she can to encourage occupation treatment. Several of the patients might be dismissed to make room for others in more need of treatment. I examined and classified the patients as shown in Table II.

Nsadzu. Is about 46 miles from Fort Jameson and is under the Dutch Reformed.Mission. There is at present no Sister in charge, but it is hoped soon to have one. Meanwhile the settlement is visited once a week 
by $\mathrm{Dr}$. Kok, the lady doctor of the mission station at Madzimoyo. I saw 38 lepers and 2 non-lepers; of these 33 were local, 3 came from Tanganyika Territory and 2 from Nyasaland. There were 4 children with leprosy. There are I, ooo acres of land, partly cultivated by the patients. The huts are in need of repair, but this is being arranged for. I examined and classified the patients as shown in Table II. Of the patients, I8 were deformed and disabled; a large proportion. There seems to be great need for an active settlement in this region, but it is not likely to flourish without trained European supervision.

Fiwila Leper Village. Is in the Mkushi District and is run by the U.M.C.A. Mrs. Munday, a trained nurse, is in charge; she is the wife of Rev. J. Munday, the priest in the mission station a few hundred yards distant. I saw 34 patients, who are classified in Table II. The settlement caters for the Lala, a very primitive tribe. Their semi-nomadic habits and the loose tribal ties make it difficult to induce them to enter a stationary leper village, even though every care and attention is paid to them. Mr. Munday gave me several interesting facts regarding these people which have a bearing on leprosy. It was easier formerly to detect leprosy when the Lala wore fewer clothes; now they tend to hide the disease, especially the women, as the knowledge that they are lepers may interfere with their chances of marriage. The totemic system is strong among these people, and interferes with tribal discipline; also the contact with European and other outside influences is having the same effect. Leprosy tends to spread when the tribal discipline of primitive people becomes bad. The people of this tribe are badly undernourished, as game has become scarce; they are dirty, covered with scabies, infected with worms and venereal disease. The leper village is doing excellent work. Water is laid on and shower baths are provided; the patients are kept happy and industrious, busy with agriculture and various industries.

Mongu. Here at the Government headquarters of Barotseland there is a leper camp attached to the General Government Hospital, with 18 patients. In company with Dr. Jamieson, the Medical Officer, I examined these and 2I out-patients, and classified them as given in Table II. There were 9 others who appeared as lepers, but in whom I found no signs of leprosy; apparently there is a desire to be diagnosed as a leper, as the government tax is remitted. The in-patients get free huts and rations, and in addition are paid for work done. The number of lepers in the camp is no indication of the numbers in the district.

Balovale. On the upper Zambesi is the headquarters of the northern district of Barotseland. The leper camp is attached to the General Hospital and is supervised by the Medical Officer. I examined the 37 patients in company with Dr. Will, and discussed the method of dealing with them administratively with Mr. Jones, the District Commissioner. The classification is given in Table II. The patients are dirty, and many of them suffer from scabies. In spite of their proximity to the Zambesi they are not fond of washing.

Chitokoloki. This mission settlement lies about 2 I miles south of Balovale on the Zambesi. Unfortunately time did not permit a visit. I understand there are between 30 and 40 patients.

Chilubi. On this island in Lake Bangweulu there is a small leper settlement under the White Fathers, of which Dr. Meiklejohn is in charge. Unfortunately I was unable to visit it, but I had an opportunity of discussing leprosy as it exists in that region with Dr. Meiklejohn. On the island of Chilubi itself, with its rooo inhabitants, there are said to be roo lepers, and the disease is supposed to be very common among the Babisa tribe who live between the lake and the Luapula River. These people are said to be very dirty and infested with hookworm and other worms; jiggers is particularly bad. Their food is casava and fish, but they are undernourished and suffer from scurvy. In the settlement itself, which is increasing in size, there are at present 33 cases, but of these there are only 4 severe open cases. Apparently the resistance is fairly high, but the disease is spread by the promiscuousness and insanitary habits of the people. Among the Bemba tribe to the east of the lake leprosy is not common; they are more sanitary and feed on millet and not casava. 
Sugicistions

(I) Tax Remission. A large proportion, probably a majority, of lepers who are exempted from taxes have only a few tuberculoid lesions which would heal up within six months under active treatment. I therefore suggest that in these cases, tax should only be exempted on medical certification that treatment is being taken regularly. Treatment of tuberculoid patches by intradermal injections of hydnocarpus oil and with caustics should then popularise treatment centres, when it is seen that this type of the disease clears up quickly, and when the counter-attraction of tax remission no longer exists. Much money could thus be saved to Government and the control of leprosy would be facilitated.

(2) Recognition of Leprosy by Officials and Others. I consider it is highly important that all Government officials who have to deal with tax-exemption should be acquainted with the appearances of the various forms of leprosy and the nature of the disease. They, and also missionaries, teachers and others who are in constant touch with the people, could do much to prevent leprosy if they were acquainted with the more important facts about the disease.

(3) Traininy of Medical Orderlics. I consider also that not only Medical Officers, but medical orderlies under their supervision, should be trained to recognise and treat leprosy. Possible means of arranging for this training are mentioned below.

(4) Need of First Ciass Settlement. There are at present in Northern Rhodesia a number of small leper settlements and camps, but none of these has an expert whole-time worker in charge. I consider it important that there should be at least one centre managed by a whole-time expert who has already been trained at a large modern leprosy institution. I suggest that the Medical Department apply to the British Empire Leprosy Relief Association for the free services of one of the staff of Toc $\mathrm{H}$ Sanitary Workers who are trained in the modern methods in use in Nigeria, his salary and travelling expenses outside the country to be paid by the Association, and accommodation and travelling inside the country to be provided by Government.

(5) Site of Settlement. In choosing a site for a first-class settlement it is important that it should be situated in the midst of a highly endemic area. Before definitely fixing a site a survey of the surrounding area should be made to determine at least approximately the amount of leprosy.

(6) Survey of Balouale District. I suggest therefore that if a special leprosy worker is appointed he should first of all make 
a rough survey of the Balovale District which appears to have the largest incidence of leprosy, and that, if found sutable, this should be selected as the site.

(7) Training Centri. Once a settlement was established it could be used as a training centre; also the special officer could pay visits to other settlements, advise regarding improved methods and carry out training at any centre where leprosy is being treated.

(8) Leprosy Officir. The above is only a rough sketch of the work of a special leprosy officer; he would work under the Director of Medical Services and the direct supervision of the local Medical Officer; the advice of the Leprosy Association would be available as to how his services might best be used and anti-leprosy work developed.

(9) Improvements in Triatment. In visiting the various leprosy institutions I have noticed that various improvements mighe be made in treatment. Intradermal injections of tuberculoid lesions would lead to their rapid healing and the " turn over " of patients might be considerably increased. I have demonstrated new methods to those in charge, but one of the main requirements is an effective uniformly non-irritant hydnocarpus preparation. I suggest that this be supplied to all leprosy treatment centres by the Medical Department in bottles, ready for use, in the form of creosoted hydnocarpus oil. This can be obtained in two pound tins from a reliable Indian firm and prepared according to instructions in a note recently sent out by the Association (see the July, 1939, number of the Leprosy Review). Each consignment should be sent out along with printed instructions as given in the above mentioned note. The oil should be ordered once a year from India, with instructions to send the bill to the Leprosy Association for payment. All the oil should be bottled in one pound or half pound bottles, creosoted, sterilised and stored till required. This suggestion and offer also apply to Nyasaland.

(10) Leprosy Expert for East Africa. Much good work is being done by the missions in attending the lepers, but this could be increased considerably if there were expert medical supervision. In my last year's report on East Africa I recommended the appointment of a Leprosy Expert who would visit in succession the various British territories, spending a few weeks or months at each leprosy treatment centre. B.E.L.R.A. has offered to pay $£ 350$ a year for five years towards the expense, provided the remainder is met by the various territories participating. I believe that a suitable expert is available, who has been approved by the Colonial Office. The leprosy work in Northern Rhodesia and Nyasaland wauld undoubtedly benefit greatly by joining in such a scheme. 